\title{
THE BUTTERFLY (INSECTA: LEPIDOPTERA) DIVERSITY OF FOUR SACRED GROVES OF GOA, INDIA
}

\author{
Kiran Gaude ${ }^{1}$ \& M.K. Janarthanam ${ }^{2}$ \\ 1,2 Department of Botany, Goa University, Goa 403206, India \\ ${ }^{1}$ kiran.gaude@gmail.com (corresponding author), ${ }^{2}$ jana@unigoa.ac.in
}

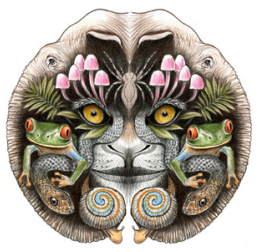

ISSN 0974-7907 (Online) ISSN 0974-7893 (Print)

OPEN ACCESS
Abstract: The butterfly diversity of four sacred groves in Goa, viz., Nirankarachi Rai, Alvatinichi Rai, Mharinginichi Rai and Azobhachi Rai was selected for study purposes. A total of 33 species belonging to 31 genera were observed which accounts for about $13 \%$ of the species recorded from Goa. The Family Nymphalidae dominated with a high number of species with maximum diversity in Mharinginichi Rai. It is concluded that further studies on groves from different habitats will significantly increase this number.

Keywords: Butterflies, Goa, species richness, sacred grove.

In ancient India, many communities practiced different forms of worshiping mother nature (Gadgil \& Vartak 1974). One of the traditions is to protect forest patches designating them as sacred groves, dedicated to deities or ancestral spirits (Yadav et al. 2010). Over 13,720 sacred groves have been enlisted from India (Malhotra et al. 2001). Goa, a small state with an area of $3,702 \mathrm{~km}^{2}$ is covered by $1424.38 \mathrm{~km}^{2}$ of forests. Goa is estimated to harbour about 100 sacred groves (Rajendra Kerkar pers. comm. 2013) each reflecting unique micro climatic conditions with diverse flora and fauna.

Butterflies of Goa are fairly well documented
(Rangnekar \& Dharwadkar 2009). Sharma \& Borkar (2008) enumerated 251 species, while Rangnekar \& Dharwadkar (2009) added three more species to the state, which takes the tally to 254 species. Documentation on butterflies of the state is mostly from national parks and wildlife sanctuaries and very few attempts have been made to enlist the richness and diversity of butterflies within the sacred groves of Goa. In this study, an attempt has been made to study the butterfly fauna of four patches of sacred groves in Goa.

\section{MATERIALS AND MethodS}

Study Area: Four sacred groves, viz.: Nirankarachi Rai (NR), Alvatinichi Rai (AR), Azobachi Rai (AzoR) and Mharinginichi Rai (MR) have been studied (Fig. 1).

1. Nirankarachi Rai: The grove is located at Nanoda

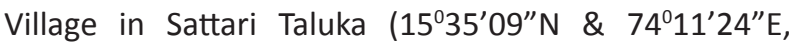
$125 \mathrm{~m})$. This grove is dedicated to the holy spirit known as "Nirankari". It is essentially a Myristica swamp and covers an area $<1$ ha. The vegetation is dominated by tree species such as Gymnacranthera canarica, Holigarna
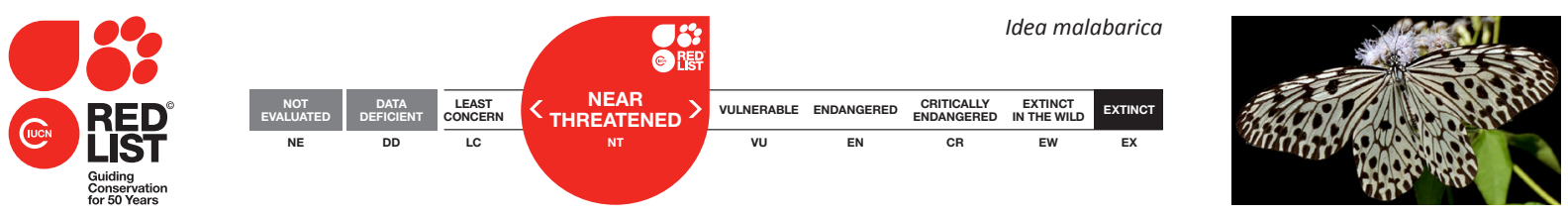

DOI: http://dx.doi.org/10.11609/JoTT.o4228.7927-32 | ZooBank: urn:Isid:zoobank.org:pub:D8E07992-5545-4A4D-AA39-02173023EA95

Editor: George Mathew, Former Emeritus Scientist, KFRI, Peechi India.

Date of publication: 26 October 2015 (online \& print)

Manuscript details: Ms \# 04228 | Received 06 February 2015 | Final received 07 September 2015 | Finally accepted 20 September 2015

Citation: Gaude, K. \& M.K. Janarthanam (2015). The butterfly (Insecta: Lepidoptera) diversity of four sacred groves of Goa, India. Journal of Threatened Taxa 7(12): 7927-7932; http://dx.doi.org/10.11609/JoTT.04228.7927-32

Copyright: () Gaude \& Janarthanam 2015. Creative Commons Attribution 4.0 International License. JoTT allows unrestricted use of this article in any medium, reproduction and distribution by providing adequate credit to the authors and the source of publication.

Funding: Ministry of Environment and Forests (27/7/2011-(SG)-RE dt.28/3/2012).

Conflict of Interest: The authors declare no competing interests.

Acknowledgements: The authors are thankful to the Ministry of Environment and Forests (27/7/2011-(SG)-RE dt. 28/3/2012) for funding support. 
grahamii, Polyalthia fragrans and Lophopetalum wightianum.

2. Alvatinichi Rai: The grove devoted to goddess "Alvatin" is located near Netravali Wildlife Sanctuary at Savari Village $\left(15^{\circ} 04^{\prime} 03^{\prime \prime} \mathrm{N} \& 74^{\circ} 13^{\prime} 30^{\prime \prime} \mathrm{E}, 122.3 \mathrm{~m}\right)$, and covers an area $<1 \mathrm{ha}$. The grove is bounded by agricultural land and thick evergreen forest. Like Nirancharachi Rai, this grove has unique Myristica swamp forests and is dominated by trees belonging to Myristicaceae as well as Hydnocarpus pentandra - an endemic tree species.

3. Mharinginichi Rai: It is located in Pissurlem Village of Sattari Taluka $\left(15^{\circ} 31^{\prime} 40^{\prime \prime} \mathrm{N} \& 7^{\circ} 04^{\prime} 02^{\prime \prime} \mathrm{E}, 46.7 \mathrm{~m}\right)$ devoted to Dev Mharingan and managed by villagers. It covers about a 2 ha area with elements of semi-evergreen forest. The grove is surrounded by a coconut plantation, grassland and degraded forest on lateritic plateau. The vegetation is dominated by trees such as Hydnocarpus pentandra, Garcinia indica, Holigarna arnottiana, Ficus benghalensis, F. religiosa, F. exasperata and F. arnottiana and Persea macrantha. However, the area was more or less degraded with Chromolaena odorata occupying

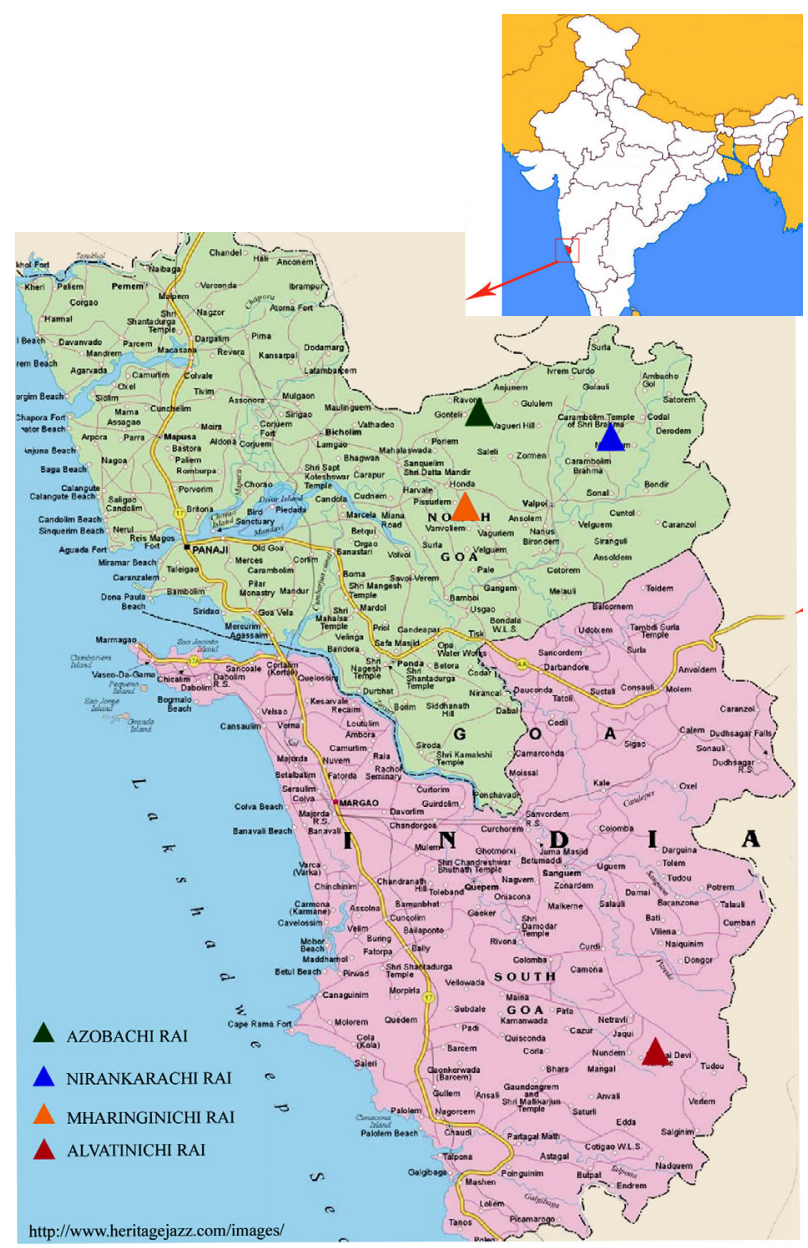

Figure 1. Study sites in Goa most of the degraded areas. In addition, shrubs such as Carissa carandas, Ziziphus rugosa, Ziziphus oenopolia, Clerodendrum infortunatum and Ixora coccinea are common.

4. Azobachi Rai: Azobachi Rai $\left(15^{\circ} 36^{\prime} 27^{\prime \prime} \mathrm{N}\right.$ \& $74^{\circ} 04^{\prime} 44^{\prime \prime} E, 247.8 \mathrm{~m}$ ) is conserved in the name of Azoba at Keri Village, Sattari Taluka and covers about 11 ha area which is surrounded by the Sahyadri mountain ranges. The vegetation is dominated by tress such as Ficus arnottiana, F. callosa, F. carica and F. nervosa, Terminalia paniculata including endemic species such as Aglaia elaegnoidea, Holigarna grahamii, Polyalthia fragrans and Nothopegia castaneifolia. Shrubs such as Allophylus cobbe, Clerodendrum infortunatum, Flemingia strobilifera, Ixora coccinea and Leea indica are common. Lianas and stragglers form an important component and they include Calamus thwaitesii, Diploclisia glaucescens, Gnetum ula, Calycopteris floribunda, Callicarpa tomentosa, etc.

The butterflies covered in this study were identified in the field visually with the help of the photographic guides of Rangnekar (2007) and Kunte (2000). The Identity of some of the taxa was confirmed by Mr. Parag Rangnekar. Photographs were taken using a Nikon D5100 (Image 1a-h).

\section{RESULTS AND DISCUSSION}

The four studied sacred groves constitute about 15 ha area. A total of 33 species belonging to 31 genera were observed which constitutes $13 \%$ of the butterfly diversity (Table 1) of the state. This included 18 species of Nymphalidae and five species each from Papilionidae, Pieridae and Lycaenidae. The faunal elements were of interest in that it contained two endemic species, viz., Southern Birdwing Troides minos and Malabar Tree Nymph Idea malabarica. The former is protected under Schedule-I of the Wildlife (Protection) Act, 1972, while the latter is near threatened (Lepidoptera Specialist Group 1996). This indicates the importance of sacred groves. The family Nymphalidae was dominant in all the four sacred groves (Fig. 2), as it is the largest family of butterflies. One of the reasons for its dominance might be the availability of their larval food plants which was also reviewed by Murugesan et al. (2013). A similar pattern of dominance was observed by different authors (Kunte 1997, Kunte et al. 1999; Arun 2000; Devi \& Devidar 2001; Eswaran \& Pramod 2005; Kumar et al. 2007; Dolia et al. 2008; Krishnakumar et al. 2008; Ramesh et al. 2010; Gogoi 2012; Murugesan et al. 2013).

With regard to the number of species recorded from the various patches of sacred groves, 22 were 
Table 1. Checklist of butterflies with their scientific names and their occurrence in different groves

\begin{tabular}{|c|c|c|c|c|c|c|}
\hline & Family/Common Names & Scientific Names & MR & AR & AzoR & NR \\
\hline \multicolumn{7}{|c|}{ Paillionidae } \\
\hline 1 & Blue Mormon & Papilio polymnestar (Cramer) & & + & + & \\
\hline 2 & Common Rose & Pachliopta aristolochiae Fabricius & + & + & + & \\
\hline 3 & Common Mormon & Papilio polytes Linnaeus & + & + & & \\
\hline 4 & Southern Birdwing & Troides minos Cramer & & + & & \\
\hline 5 & Tailed Jay & Graphium agamemnon Linnaeus & & & + & \\
\hline \multicolumn{7}{|c|}{ Pieredae } \\
\hline 6 & Common Grass Yellow & Eurema hecabe Moore & + & + & + & \\
\hline 7 & Common Wanderer & Pareronia valeria hippia Cramer & + & + & & \\
\hline 8 & Pioneer & Anaphaeis aurota (Fabricius) & & + & & \\
\hline 9 & Common Jezebel & Delias eucharis Drury & + & & & \\
\hline 10 & Common Emigrant & Catopsilia crocale Fabricius & + & & & \\
\hline \multicolumn{7}{|c|}{ Lycaenidae } \\
\hline 11 & Lesser Grass Blue & Zizina otis indica Murray & + & & & \\
\hline 12 & Pale Grass Blue & Zizeeria maha ossa (Swinhoe) & & + & & \\
\hline 13 & Common Pierrot & Castalius rosimon rosimon Fabricius & + & & & \\
\hline 14 & Suffused Double-banded Judy & Abisara bifasciata suffusa Moore & + & & & \\
\hline 15 & Malayan & Megisba malaya (Horsfield) & & + & & \\
\hline \multicolumn{7}{|c|}{ Nymphalidae } \\
\hline 16 & Common crow & Euploea core core (Cramer) & + & + & + & \\
\hline 17 & Rustic & Cupha erymanthis Frushstorfer & + & + & + & + \\
\hline 18 & Striped Tiger & Danaus genutia (Cramer) & & & + & \\
\hline 19 & Common Evening Brown & Melanitis leda (Drury) & + & & + & \\
\hline 20 & Chocolate Pansy & Precis iphita (Cramer) & & + & + & \\
\hline 21 & Common Sailer & Neptis hylas (Moore) & + & + & + & \\
\hline 22 & Glassy Tiger & Parantica aglea Stoll & + & & + & \\
\hline 23 & Grey Pansy & Precis atlites (L.) & + & + & & \\
\hline 24 & Grey Count & Tanaecia lepidea Frushstorfer & + & & & \\
\hline 25 & Common Four Ring & Ypthima huebneri (Kirby) & + & & & \\
\hline 26 & Common Sergent & Athyma perius (Linnaeus) & + & & & \\
\hline 27 & Malabar Tree Nymph & Idea malabarica (Moore) & + & + & & + \\
\hline 28 & Plain Tiger & Danaus chrysippus (Linnaeus) & + & + & & \\
\hline 29 & White Four-ring & Ypthima ceylonica (Hewitson) & & + & & \\
\hline 30 & Common Bush Brown & Mycalesis perseus typhlus Fruhstorfer & & + & & \\
\hline 31 & Tamil Yeoman & Cirrochroa thais thais (Fabricius) & + & + & + & \\
\hline 32 & Nigger & Orsotriaena medus (Fabricius) & + & & & \\
\hline 33 & Blue Tiger & Tirumala limniace exoticus Gmelin & & + & & \\
\hline
\end{tabular}

MR - Mharinginichi Rai; AR - Alvatinichi Rai; AZOR - Aazobachi Rai; NR - Nirancharachi Rai

from MR, 20 species from AR, 12 species from AzoR and two species from NR. The species composition of the various patches of sacred groves was also interesting. A total of nine species, viz., the Common Jezebel Delias eucharis, Common Emigrant Catopsilia crocale, Lesser Grass Blue Zizina otis indica, Common Pierrot Castalius rosimon rosimon, Suffused Double-banded Judy Abisara bifasciata suffuse, Grey Count Tanaecia lepidea, Common Four Ring Ypthima huebneri, Common Sergent Athyma perius and Nigger Orsotriaena medus were seen only in
Mharinginichi Rai. The Common Bush Brown Mycalesis perseus typhlus, White Four-ring Ypthima ceylonica, Malayan Megisba malaya, Pale Grass Blue Zizeeria maha ossa, Pioneer Anaphaeis aurota and Southern Birdwing Troides minos were sighted only in Alvatinichi Rai. The latter is an endemic species to Peninsular India and was sighted twice on subsequent days during the morning hours in January 2014 and was found visiting this grove from the nearby evergreen forest. The Tailed Jay Graphium agamemnon and Striped Tiger Danaus 


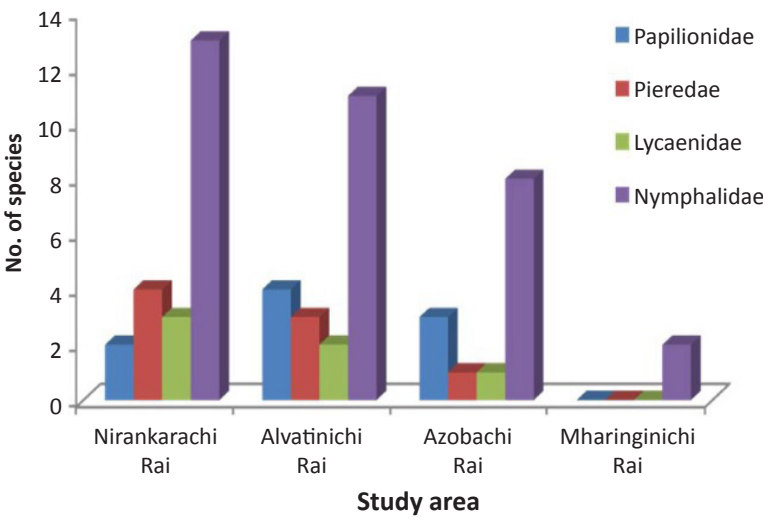

Figure 2. Family wise distribution of butterfly species in four sacred groves of Goa

genutia were sighted exclusively in Azobachi Rai. Rustic Cupha erymanthis is the only species which has been recorded from all the four groves. Bray-Curtis analysis was used to analyse the similarity between the four sites (Table 2) based on the presence and absence of butterfly species. Maximum similarity was observed between MR and AR (52.38\%) and the least was observed between AzoR and NR (14.29\%).

MR shows a maximum butterfly species richness ( 22 species) and the reasons might be high plant diversity which provides host and food plants for butterflies. This grove is infested with Chromolena odorata which is known for high nectar production (Laxmi \& Solomon Raju 2011). This may be one of the reasons for the high number of butterfly species as it provides abundant nectar. This grove is also surrounded by a lateritic plateau and grassy plains which provide additional suitable habitats for butterflies and creates wide scope for food plants. Butterflies from adjacent areas may be visiting and contributing to the butterfly diversity. AR is a swamp forest dominated by Myristicaceae members and is surrounded by agricultural fields and evergreen forest. Evergreen forest provides good habitat for butterflies hence the AR has more diverse butterfly species ( 20 species) compared to AzoR and NR. AzoR is a thick forested area dominated by liana species. This grove is not infested with weeds while the adjacent areas of AzoR is surrounded by cashew plantation and were completely infested with the weed $C$. odorata. Butterfly diversity has been observed to be more towards the boundaries of the groves as compared to interior with more native species. AzoR has less number of butterfly species (12 species) as compared to MR and AR. Light is an important factor for butterfly assemblage (Hill et al. 2001) and it is associated with increased butterfly diversity (Sparrow et al. 1994). This could be the reason
Table 2. Similarity Matrix of distribution of butterfly species in four sacred groves.

\begin{tabular}{|l|c|c|c|c|}
\hline \multicolumn{5}{|c|}{ Similarity Matrix } \\
\hline MR & MR & AR & AzoR & NR \\
\hline AR & $*$ & 52.381 & 47.0588 & 16.6667 \\
\hline AzoR & $*$ & $*$ & 50 & 18.1818 \\
\hline NR & $*$ & $*$ & $*$ & 14.2857 \\
\hline
\end{tabular}

MR - Mharinginichi Rai; AR - Alvatinichi Rai; AZOR - Aazobachi Rai; NR Nirancharachi Rai

for less butterfly diversity as AzoR is a thick forested area and its surroundings provide a well lighted environment and nectar source through invasive plant species. Similar views regarding the importance of invasive species for butterfly species richness was also expressed by Raju \& Reddy (1995) and Borkar \& Komarpant (2004). NR is the smallest among all four sacred groves. Like AR this grove has less plant diversity, but characteristically dominated by family Myristicaceae and has the least butterfly species (2 species). The Malabar tree nymph Idea malabarica is found to be the commonest species at NR. Plant families such as Rutaceae, Aristolochaceae, Fabaceae, Poaceae, Rhamnaceae, Apocynaceae, Moraceae, Capparidaceae which provide a large number of host species (Kunte 2000) are not observed in NR. NR is surrounded by agricultural fields and rubber plantations which do not provide any suitable habitat for butterflies. A small area, less plant diversity and adjacent paddy fields may be the major factors for less number of butterfly species observed here. Similarity among the sites, based on the butterfly species distribution, varies from 14.29- 52.38 $\%$. This shows that the distribution of butterfly species also depends on the vegetation type apart from other factors.

\section{CONCLUSION}

From the study it is concluded that generally sacred groves with high plant diversity hold a high number of butterflies. Presence of endemic and Near Threatened species, viz., Southern Birdwing Troides minos and Malabar Tree Nymph Idea malabarica indicates the importance of these groves for the butterflies and their conservation. In spite of the high anthropogenic activities in Mharinginichi Rai, good diversity of flora and fauna, such groves become ecological harbours. Research efforts to gather basic information on faunal diversity, especially butterflies are needed for future effective management programmes as butterflies are good indicators of environmental quality (Gunathilagaraj 

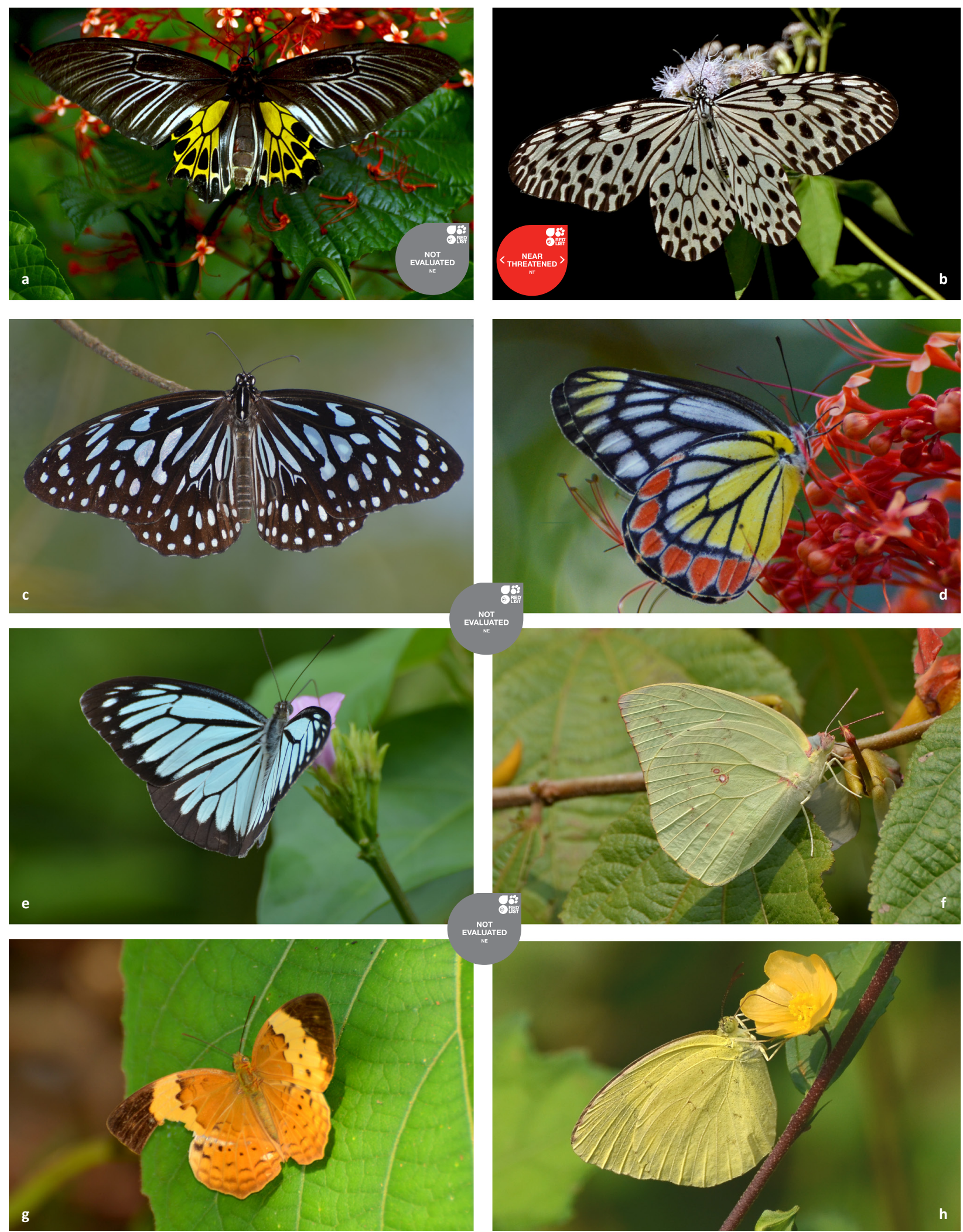

83
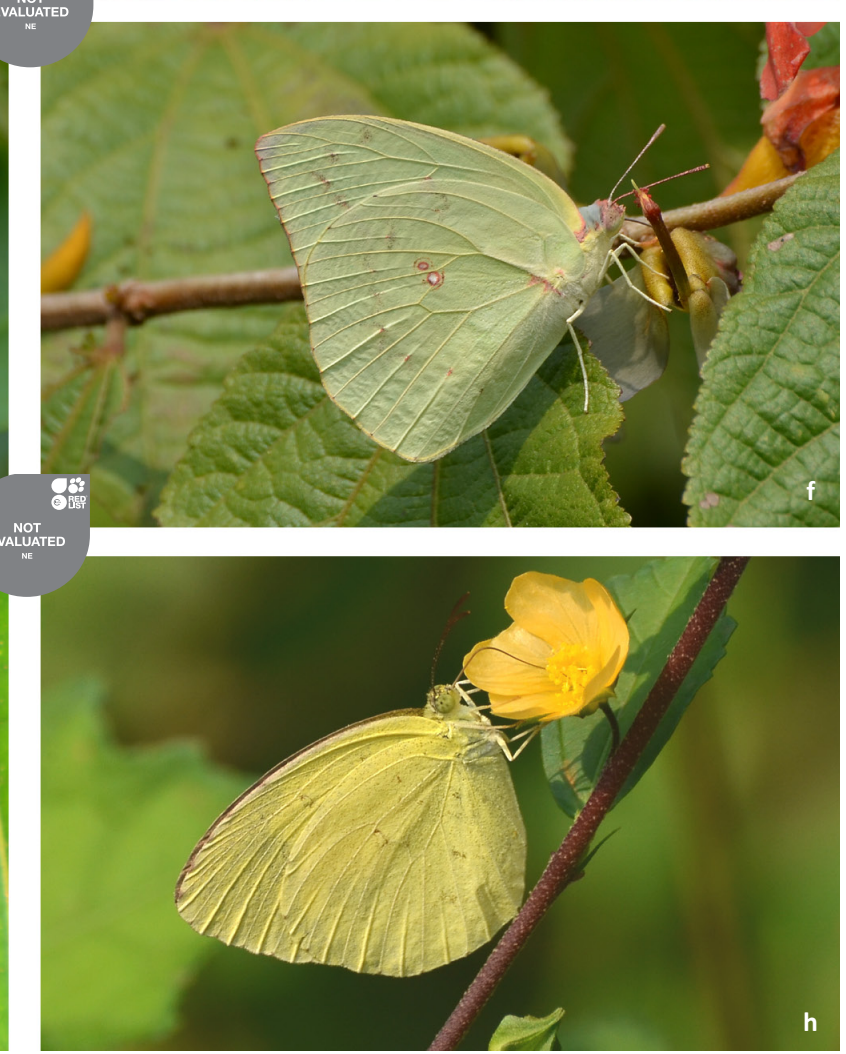

Image 1a-h. a - Troides minos; b - Idea malabarica; c - Tirumala limniace exoticus; d - Delias eucharis; e - Pareronia valeria hippia; f - Catopsilia crocale; g - Cupha erymanthis; h - Eurema hecabe. (c) Authors 
et al. 1998) and of ecological significance (Kaneria et al. 2013). It is concluded that year round work in the sacred groves of different habitats might throw some light with regard to butterfly diversity.

\section{REFERENCES}

Arun, P.R. (2000). Seasonality and abundance of insects with special reference to butterflies (Lepidoptera: Rhopalocera) in a moist deciduous forest of Siruvani, Nilgiri Biosphere Reserve, South India. PhD Thesis. Department of Zoology, Bharathiar University, Coimbatore, $236 \mathrm{pp}$.

Borkar, M.R. \& N. Komarpant (2004). Diversity, abundance and habitat associations of butterfly species in Bondla Wildlife Sanctuary of Goa, India. Zoos' Print Journal 19(10): 1648-1653; http://dx.doi. org/10.11609/JoTT.ZPJ.1192.1648-53

Devi, M.S. \& P. Davidar (2001). Response of wet forest butterflies to selective logging in Kalakad-Mundanthurai Tiger Reserve: Implications for conservation. Current Science 80(3): 400-405.

Dolia, J., M.S. Devy, N.A. Aravind \& A. Kumar (2008). Adult butterfly communities in coffee plantations around a protected area in the Western Ghats, India. Animal Conservation 11: 26-34; http://dx.doi. org/10.1111/j.1469-1795.2007.00143.x

Eswaran, R. \& P. Pramod (2005). Structure of butterfly community of Anaikatty Hills, Western Ghats. Zoos' Print Journal 20(8): 19391942; http://dx.doi.org/10.11609/JoTT.ZPJ.1330.1939-42

Gadgil, M. \& V.D. Vartak (1974). Sacred groves of India - A pleafor continued conservation. Journal of the Bombay National History Society 72(2): 314-320.

Gogoi, M.J. (2012). Butterflies (Lepidoptera) of Dibang Valley, Mishmi Hills, Arunachal Pradesh, India. Journal of Threatened Taxa 4(12) 3137-3160; http://dx.doi.org/10.11609/JoTT.o2975.3137-60

Gunathilagaraj, K., T.N.A. Perumal, K. Jayaram \& M.G. Kumar (1998). Some south Indian Butterflies. Nilgiri Wildlife and Environment Association, 253pp.

Hill, J.K., K.C. Hamper, J. Tangah \& M. Dawood (2001). Ecology of tropical butterflies in rainforest gaps. Oecologia 128: 294-302 http://dx.doi.org/10.1007/s004420100651

Kaneria, M., M. Kaneria \& V. Kushwah (2013). Diversity of Butterflies (Lepidoptera) in Bilaspur district Chattisgarh, India. Asian Journal of Experimental Biological Sciences 4(2): 282-287.

Krishnakumar, N., A. Kumaraguru, K. Thiyagesan \& S. Asokan (2008) Diversity of Papilonid butterflies in the Indira Gandhi Wildlife sanctuary, Western Ghats, southern India. Tiger Paper 35: 1-8.

Kumar, M.P., B.B. Hosetti, H.C. Poomesha \& G.H.T. Raghavendra (2007). Butterflies of the Tiger Lion Safari, Thyavarekoppa, Shioga, Karnataka. Zoos' Print Journal 22(8): 2805; http://dx.doi. org/10.11609/JoTT.ZPJ.1594.2805
Kunte, K. (1997). Seasonal patterns in butterfly abundance and species diversity in four tropical habitats in the northern Western Ghats. Journal of Bioscience 22(5): 593-603.

Kunte, K. (2000). Butterflies of Peninsular India. University Press (India) Limited, 254pp.

Kunte, K., A. Joglekar, G. Utkarsh \& P. Pramod (1999). Patterns of butterfly, bird and tree diversity in the Western Ghats. Current Science India 29: 1-14.

Laxmi P.V. \& A.J.S. Raju (2011). Chromolaena odorata (L.) King \& H.E. Robins (Asteraceae), an important nectar source for adult butterflies. Journal of Threatened Taxa 3(2): 1542-1547; http:// dx.doi.org/10.11609/JoTT.02504.1542-7

Lepidoptera Specialist Group (1996). Idea malabarica. In: IUCN 2012. 2012 IUCN Red List of Threatened Species. Downloaded on 12 September 2014.

Malhotra, K.C., Y. Ghokhale, S. Chatterjee \& S. Srivastava (2001). "Cultural and Ecological Dimensions of Sa-cred Groves in India," Indian National Science Academy, New Delhi and Indira Gandhi Rashtriya Manav Sangrahalaya, Bhopal, 30pp.

Murugesan, M., P.R. Arun \& B.A.K. Prusty (2013). The butterfly community of an urban wetland system - a case study of Oussudu Bird Sanctuary, Puducherry, India. Journal of Threatened Taxa 5(12): 4672-4678; http://dx.doi.org/10.11609/JoTT.o3056.4672-8

Raju, A.J.S. \& C.S. Reddy (1995). Flower colourshifts and pollination in Latana camara L. Verbenaceae. Journal of Palynology 31: 275-289.

Ramesh, T., K.J. Hussain, M. Selvanayagam, K.K. Satpathy \& M.V.R. Prasad (2010). Patterns of diversity, abundance and habitat associations of butterfly communities in heterogeneous landscapes of the department of atomic energy (DAE) campus at Kalpakkam, South India. International Journal of Biodiversity and Conservation 2(4): 75-85.

Rangnekar, P. \& O. Dharwadkar (2009). Three additions to the known butterfly (Lepidoptera: Rhopalocera and Grypocera) fauna of Goa, India. Journal of Threatened Taxa 1(5): 298-299; http://dx.doi. org/10.11609/JoTT.o2140.298-9

Rangnekar, P. (2007). A Photographic Guide to Butterflies of Goa. (also includes butterflies of other ranges of the Western Ghats \& Southern India). Mineral Foundation of Goa, 66pp.

Sharma, R.M. \& M. R. Borkar (2008). Insecta: Lepidoptera: Rhopalocera and Grypocera. Fauna of Goa, State Fauna Series, Zoological Survey of India 16: 199-210.

Sparrow, H., T. Sisk, P. Ehrlich \& D. Murphy (1994). Techniques and guidelines for monitoring Neotropical butterflies. Conservation Biology 8: 800-809.

Yadav, S., J.P. Yadav, V. Arya \& M. Panghul (2010). Sacred groves in conservation of plant biodiversity in Mehendergarh District of Haryana. Indian Journal of Traditional Knowledge (4): 693-700.

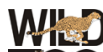

